\title{
РОЛЬ ПРОЦЕСІВ ПЕРЕКИСНОГО ОКИСНЕННЯ ЛІПІДІВ ТА АНТИОКСИДАНТНОГО ЗАХИСТУ В ШКІРІ В ДИНАМІЦІ РОЗВИТКУ ЕКСПЕРИМЕНТАЛЬНОГО КОНТАКТНОГО ДЕРМАТИТУ
}

\section{Львівський медичний інститут}

๑М. М. Регеда-Фурдичко

\begin{abstract}
РЕзюМЕ. Мета нашого дослідження - з'ясування стану прооксидантної і антиоксидантної системи в шкірі морських свинок у різні періоди формування контактного дерматиту.

Матеріал і методи. Експериментальні дослідження проводили на морських свинках, поділених на 5 груп по 9 тварин у кожній. До I групи (контроль) увійшли інтактні морські свинки, до II - тварини з експериментальним контактним дерматитом на 4-у добу, до III - морські свинки на 8-у добу модельного процесу, до IV - тварини на 10-у добу та до V-тварини на 18-у добу контактного дерматиту. 3 метою детального аналізу та інтерпретації показників прооксидантної та антиоксидантної систем у різні доби експерименту умовно виділяли два періоди розвитку експериментального контактного дерматиту: ранній і пізній. Ранній період включав групу тварин на 4-у та 8-у доби експерименту. Пізній - групу тварин на 10-у та 18-у доби контактного дерматиту.

Експериментальну модель контактного дерматиту відтворювали на морських свинках за методом В. А. Волковой (2010). Стан вільнорадикального окиснення ліпідів у шкірі визначали за вмістом дієнових кон'югатів за методом В. Г. Гаврилова, М. І. Мишкорудної (1989), вміст малонового діальдегіду - за методом Е. Н. Коробейникова (1989). Ступінь активності антиоксидантної системи оцінювали за вмістом ферментів - супероксиддисмутази за методом R. Fried (1975), каталази за методом R. Holmes, C. Masters (1970), глутатіонпероксидази - за методом О. Г. Архиповой (1988) та глутатіонредуктази - за методом В. М. Моїна (1986).

Результати. У роботі встановлено поступове зростання продуктів вільнорадикального окиснення - дієнових кон'югатів та малонового діальдегіду - на усі доби формування експериментального контактного дерматиту. Виявлено початкове підвищення активності супероксиддисмутази, каталази, глутатіонредуктази та глутатіонпероксидази в шкірі на 4-у добу, з наступним зниженням цих ферментів з 8-ї доби експерименту, що свідчило про порушення рівноваги між прооксидантною та антиоксидантною системами, особливо на 10-у і 18-у доби дослідження, що посилює запальний процес в шкірі, а також запускає каскад інших механізмів пошкодження.

КЛючОВІ СЛОВА: контактний дерматит; малоновий діальдегід; дієнові кон'югати; супероксиддисмутаза; каталаза, глутатіонпероксидаза; глутатіонредуктаза.
\end{abstract}

Вступ. У сучасному світі складно переоцінити вплив довкілля та професійних шкідливостей на здоров'я людини. Забруднення навколишнього середовища, особливо в промислово розвинених країнах, постійний контакт як у побуті, так і на виробництві, з хімічними речовинами (будівельні матеріали, метали, продукти побутової хімії, косметичні засоби), використання різноманітних препаратів для місцевого лікування та дезінфекції зумовили зростання поширеності контактних дерматитів (КД) [10]. Частота розвитку хвороби серед дорослого населення складає $15-20 \%[9,16]$.

Вивчення сучасних аспектів патогенезу будьякого захворювання неможливе без дослідження механізмів дестабілізації біологічних мембран, які складають основу багатьох патологічних реакцій організму людини, в тому числі й при захворюваннях шкіри $[4,7,12,15]$. ПОЛ - це окислювальна деградація ліпідів, яка відбувається під дією вільних радикалів і $є$ однією з основних причин пошкодження клітинних мембран та подальшої загибелі клітин унаслідок впливу активних форм кисню. Цей процес регулює ліпідний склад біомембран і мембраноасоційованих ферментів, бере участь у синтезі лейкотрієнів, простагландинів, метаболізмі катехоламінів та стероїдних гормонів, впливає на проникність мембран і транспорт речовин через них $[7,8,11]$. Відомо, що оксидативний стрес $\epsilon$ невід'ємною ланкою патогенезу різних видів дерматитів [12], тому метою нашого дослідження стало з'ясування особливостей стану прооксидантної і антиоксидантної систем у шкірі морських свинок у різні періоди формування контактного дерматиту.

Матеріал і методи дослідження. Експериментальні дослідження проводили на 51 морській свинці (самці) масою 180-220 г, які були поділені на 5 груп по 9 тварин у кожній, крім першої (15 тварин). До I групи (контроль) увійшли інтактні морські свинки, до II, III, IV i V груп - тварини з експериментальним КД на 4-у, 8-y, 10-у і 18-у доби. 3 метою детального аналізу та інтерпретації показників прооксидантної та антиоксидантної систем у різні доби експерименту умовно виділяли два періоди розвитку експериментального КД: ранній і пізній. Ранній період включав групу тварин із КД на 4-у та 8-у доби експерименту. Пізній - морських свинок на 10-у та 18-у доби КД. Вибрані 
Огляди літератури, оригінальні дослідження, погляд на проблему, випадок з практики, короткі повідомлення доби КД були обумовлені класичними стадіями запального процесу.

Експериментальний КД відтворювали на морських свинках за методом В. А. Волковой (2010) [1]. Усіх експериментальних тварин утримували в стандартних умовах віварію Львівського національного медичного університету імені Данила Галицького. Евтаназію тварин проводили шляхом декапітації під ефірним наркозом з дотриманням Європейської конвенції про захист хребетних тварин, які використовуються для експериментальних та інших наукових цілей (Страсбург, 1985). Стан ВРО ліпідів у шкірі визначали за вмістом дієнових кон'югатів (ДК) за методом В. Г. Гаврилова, М. І. Мишкорудної (1989) [2], малонового діальдегіду (МДА) - за методом Е. Н. Коробейникова (1989) [3]. Ступінь активності АОС оцінювали за вмістом ферментів - супероксиддисмутази (СОД) за мето-

дом R. Fried (1975) [13], каталази (КТ) за методом R. Holmes, C. Masters (1970) [14], глутатіонпероксидази (ГПО) - за методом Архиповой О.Г. (1988) [6] та глутатіонредуктази (ГР) - за методом В. М. Моїна (1986) [5]. Статистичне опрацювання одержаних даних здійснювали за методом Стьюдента.

Результати й обговорення. Результати біохімічних досліджень свідчать, що у тварин за умов розвитку експериментального контактного дерматиту наявні характерні ознаки розвитку оксидативного стресу. Це проявляється послідовним нагромадженням продуктів ліпопероксидації в шкірі в усі періоди формування контактного дерматиту. Зокрема, вміст ДК зростав на 30,8 \%, $59,2 \%, 67,9 \%$ і $82,7 \%(p \leq 0,05)$ відповідно на 4-y, 9-у, 10-у і 18-у доби, порівняно з інтактними тваринами, що свідчить про стимуляцію процесів вільнорадикального окиснення (рис. 1).

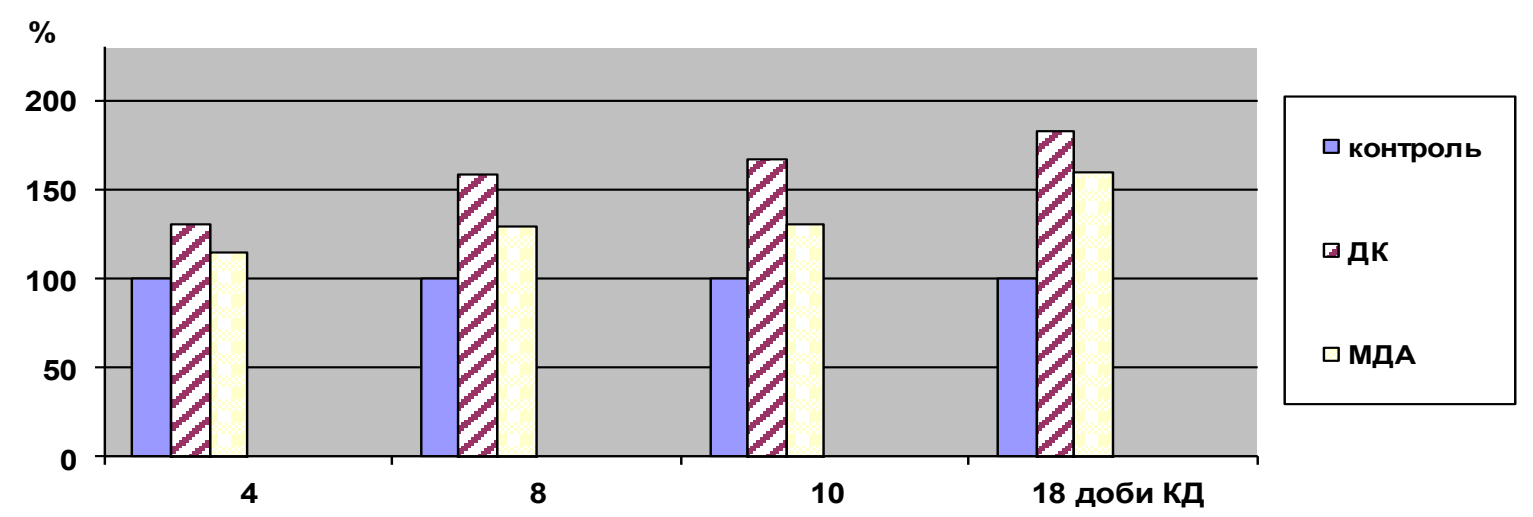

Рис. 1. Вміст продуктів пОЛ у шкірі морських свинок в динаміці формування КД (\% від контролю).

Визначення вмісту МДА в шкірі дало можливість встановити поступове його зростання на $14,6 \%(p \leq 0,05)$ на 4-у добу і на $29,2 \%(p \leq 0,05)$ на 8-y добу КД, на 10-у і 18-у доби, відповідно, на 30,8 \% і $60,5 \%(p \leq 0,05)$, порівняно з контрольними величинами, що вказує на стимуляцію прооксидантної системи і надмірне утворення продуктів перекисного окиснення ліпідів, особливо в пізній період цієї експериментальної моделі хвороби.

Виявлено неодноспрямовані зміни активності ферментів антиоксидантної системи в шкірі тварин за умов формування контактного дерматиту протягом усіх періодів розвитку експерименту. При визначенні активності СОД в шкірі виявлено поступове ії підвищення на $11,2 \%(p \leq 0,05)$ на 4-у і на $21,9 \%(p \leq 0,05)$ на 8-у доби КД, порівняно 3 першою групою морських свинок (рис. 2). Пізніше, на 10-у та 18-у доби експерименту, виявлено достовірне ії зниження, відповідно, на $39,2 \%$ $(p \leq 0,05)$ та на $43,0 \%(p \leq 0,05)$ проти показників інтактної групи, що вказує спочатку на стимуляцію, а згодом на супресію досліджуваного ензиму.
Аналогічний напрям змін встановлений під час дослідження активності каталази в шкірі. Так, на 4-у і 8-у доби КД виявлено підвищення ії активності відповідно на $11,7 \%(p \leq 0,05)$ та на $28,7 \%$ $(p \leq 0,05)$, а вже в пізній період цієї експериментальної моделі хвороби спостерігається зниження активності КТ на $37,7 \%(p \leq 0,05)$ та на $44,2 \%(p \leq 0,05)$ на 10-у та на 18-у доби, порівняно з контролем, що дає підставу стверджувати про пригнічення антиоксидантного захисту (рис. 2).

Важливими маркерами, які доповнюють характеристику попередніх, $\epsilon$ глутатіонпероксидаза та глутатіонредуктаза. Ранній період формування КД супроводжувався зростанням активності ГПО в шкірі на $26,0 \%(p \leq 0,05)$ та $65,2 \%(p \leq 0,05)$, а ГР на $40,0 \%(p \leq 0,05)$ та 60,0\% $(p \leq 0,05)$ проти інтактної групи відповідно на 4-у і на 8-у доби експерименту. Протилежні зміни досліджуваних показників у шкірі морських свинок фіксуємо в подальші доби розвитку контактного дерматиту. Активність ГПО знижується на $47,8 \%(p \leq 0,05)$ та на $52,1 \%(p \leq 0,05)$ відповідно на 10-у та на 18-у доби, порівняно 3 
Огляди літератури, оригінальні дослідження, погляд на проблему, випадок з практики, короткі повідомлення I групою тварин. Відносно активності ГР, зафіксо- $\quad(p \leq 0,05)$ на 10-у добу та на $80,0 \%(p \leq 0,05)$ на 18-у вано ще вагоміше його зниження на 60,0 \% добу КД, порівняно з контролем (рис. 2).

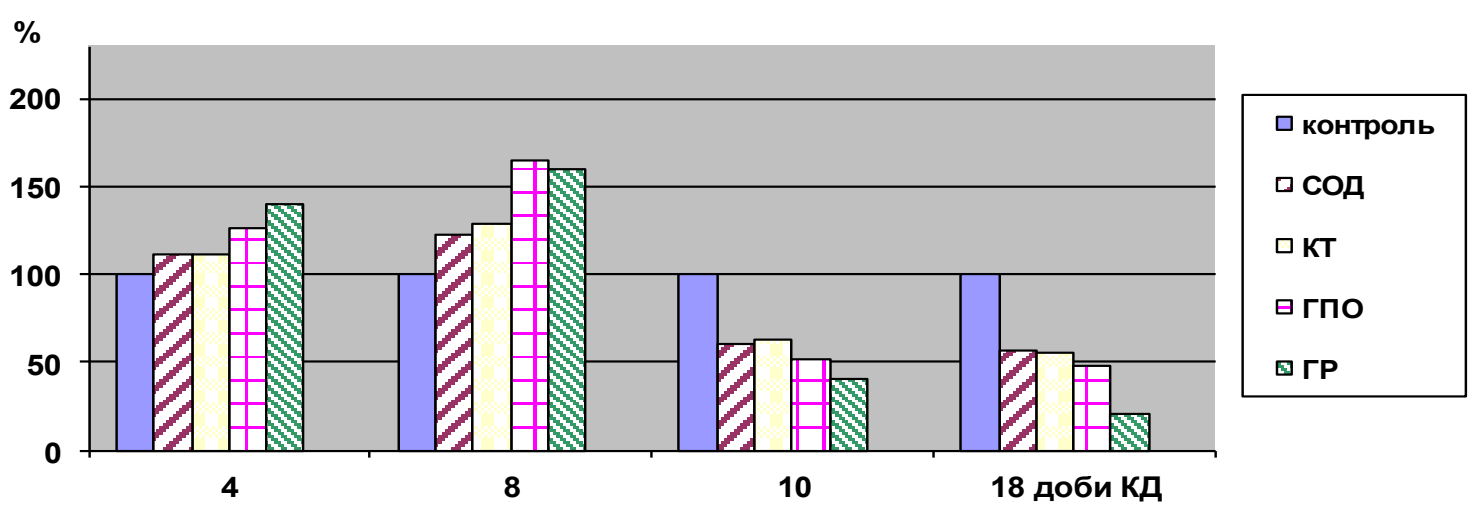

Рис. 2. Активність ферментів АОС у шкірі морських свинок в динаміці формування КД (\% від контролю).

Висновки. Підсумовуючи отримані результати дослідження можна стверджувати, що усі періоди розвитку експериментального контактного дерматиту характеризуються порушенням функціонального стану прооксидантної і антиоксидантної систем, яке проявляється надмірним накопиченням продуктів ПОЛ (зростають рівні ДК і МДА) та різноспрямованими змінами системи антиоксидантного захисту: спочатку відбулося зростання активності ферментів СОД, КТ, ГР, ГПО, як можливий компенсаторний механізм, а потім їх зниження, що свідчило про порушення клітинного гомеостазу та розвиток оксидативного стресу, особливо на 10-у і 18-у доби дослідження, що посилює запальний процес у шкірі, а також запускає каскад інших механізмів пошкодження.

Перспективи подальших досліджень. У подальшому планується дослідження прооксидантної та антиоксидантної системи в шкірі морських свинок у динаміці розвитку експериментального контактного дерматиту при експериментальній пневмонії.

\section{ЛІТЕРАТУРА}

1. Волкова В. А. Вивчення лікувальної ефективності нової мазі з ліпофільним комплексом із кори осики «Тремулін» за умов неалергічного контактного дерматиту в щурів / В. А. Волкова, І. В. Кучинська, Т. І. Тюпка // Фармакологія та лікарська токсикологія. - 2010. - С. 7-12.

2. Гаврилов В. Б. Спектрофотометрическое определение содержания гидроперекисей липидов в плазме крови / В. Б. Гаврилов, М. И. Мишкорудная // Лабораторная диагностика ишемической болезни сердца. - К. : Здоровье, 1989. - С. 170-171.

3. Коробейникова Э. Н. Модификация определения продуктов ПОЛ в реакции с тиобарбитуровой кислотой / Э. Н. Коробейникова // Лабораторное дело. 1989. - № 7. - С. 8-10.

4. Литвинець $€$. А. Перекисне окиснення ліпідів та антиоксидантний захист у разі патології сечовидільної системи, доцільність використання біофлавоноїдів у комплексному лікуванні / Є. А. Литвинець, Я. В. Гоцуляк // Здоровье мужчины. - 2012. - № 1. - С. 135-137.

5. Моин В. М. Простой и специфический метод определения активности глутатионпероксидазы в эритроцитах / В. М. Моин // Лабораторное дело. - 1986. № 12. - C. 724-727.
6. Определение активности пероксидазы в крови // Методы исследования в профпатологии / под ред. О. Г. Архиповой. - М. : Медицина, 1988. - С. 153.

7. Процеси ліпопероксидації та стан АО системи в міокарді щурів за умов інтоксикації антрацикліновими антибіотиками / І. В. Ніженковська, О. І. Ніженковський, В. В. Вільчинська [та ін.] // Сучасні проблеми токсиколоriï. - 2012. - № 2. - C. 45-47.

8. Тяжка О. В. Стан перекисного окислення ліпідів та антиоксидантної системи у дітей різного віку / О. В. Тяжка, Я. М. Загородня // Перинатология и педиатрия. 2016. - № 2. - С. 101-105.

9. Худан-Цільо І. І. Структурні зміни шкіри при контактному нікелевому дерматиті / І. І. Худан-Цільо, М. М. Корда // Вісник морфології. - 2017. - № 2, T. 3.- C. 198-202.

10. Allergic Contact Dermatitis / L. Kostner, F. Anzengruber, C. Guillod [et al.] // Immunol. Allergy Clin. North Am. - 2017. - No. 37 (1). - P. 141-152.

11. Proceedings of the Global IAD Expert Panel. Incontinence associated dermatitis: moving prevention forward / D. Beeckman, J. Campbell, D. Chimentro [et al.] // Wounds International. - 2015. - 21 p. 
Огляди літератури, оригінальні дослідження, погляд на проблему, випадок з практики, короткі повідомлення

12. Ji H. Oxidative stress in atopic dermatitis / H. Ji, X. K. Li // Oxidative Medicine and Cellular Longevity. 2016. - No. 4. - P. 261-265.

13. Fried R. Enzymatic and non-enzymaticassay of superoxide ifilii / R. Fried // Biochemie. - 1975. - Vol. 57, No. 5. - P. 657-660.

14. Holmes R. Epigenetic interconversions of the multiple forms of mouse liver catalase / R. Holmes // FEBS Lett. - 1970. - Vol. 11, No. 1. - P. 45-48.

\section{REFERENCES}

1. Volkova, V.A., Kuchynska, I.V., \& Tiupka, T.I. (2010). Vyvchennia likuvalnoi efektyvnosti novoi mazi z lipofilnym kompleksom iz kory osyky "Tremulin" za umov nealerhichnoho kontaktnoho dermatytu $v$ shchuriv [Study of the therapeutic efficacy of a new ointment with a lipophilic complex of the Tremulin aspen bark under conditions of non-allergic contact dermatitis in rats]. Farmakolohiia ta likarska toksykolohiia - Pharmacology and Drug Toxicology, 7-12 [in Ukrainian].

2. Gavrilov, V.B., \& Mishkorudnaya, M.I. (1989). Spektrofotometricheskoye opredeleniye soderzhaniya gidroperekisey lipidov v plazme krovi. Laboratornaya diagnostika ishemicheskoy bolezni serdtsa [Spectrophotometric determination of lipid hydroperoxides in blood plasma. Laboratory diagnosis of coronary heart disease]. Kyiv: Zdorovia [in Ukrainian].

3. Korobeynikova, E.N. (1989). Modifikatsiya opredeleniya produktov POL $v$ reaktsii s tiobarbiturovoy kislotoy [Modification of determination of LP products in reaction with thiobarbituric acid]. Laboratornoe delo - Laboratory Matter, 7, 8-10 [in Russian].

4. Lytvynets, E.A., \& Hotsuliak, Ya.V. (2012). Perekysne okysnennia lipidiv ta antyoksydantnyi zakhyst u razi patolohii sechovydilnoi systemy, dotsilnist vykorystannia bioflavonoidiv u kompleksnomu likuvanni [Lipid peroxidation and antioxidant protection in case of pathology of the urinary system, expediency of using bioflavonoids in complex treatment]. Zdorovye muzhchyny - Health of a Man, 1, 135137 [in Ukrainian].

5. Moin, V.M. (1986). Prostoy i spetsificheskiy metod opredeleniya aktivnosti glutationperoksidazy v eritrotsitakh [Simple and specific method of determination of activity of glutathion reductase in erythrocytes]. Laboratornoe delo - Laboratory Matter, 12, 724-727 [in Russian].

6. Arkhipova, O.G. (Ed.). (1988). Opredelenie aktivnosti peroksidazy v krovi. Metody issledovaniya v profpatologii [Determination of peroxidase activity in the blood]. Moscow: Meditsina [in Russian].

7. Nizhenkovska, I.V., Nizhenkovskiy, O.I., Vilchinska, V.V., Filipova, K.Yu., \& Chumak, N.Ye. (2012). Protsesy
15. Kubesy A. A. Altered blood oxidative stress biomarkers in association with canine pyoderma and allergic contact dermatitis / A. A. Kubesy, N. Y. Salem, A. H. Jaheen // Comparative Clinical Pathology. - 2017. - No. 26 (3). P. 643-646.

16. The burden of skin disease in the United States / H. W. Lim, S. A. Collins, J. S. Resneck [et al.] // Journal of the American Academy of Dermatology. - 2017. P. 958-972.

lipoperoksydatsii ta stan AO systemy v miokardi shchuriv za umov intoksykatsii antratsyklinovymy antybiotykamy [Processes of lipoperoxidation and state of AO systems in myocardium of rats under condition of intoxication of antracylic antibiotics]. Suchasni problemy toksykolohii - Modern Problems of Toxicology, 2, 45-47 [in Ukrainian].

8. Tiashka, O.V., \& Zahorodnia, Ya.M. (2016). Stan perekysnoho okyslennia lipidiv ta antyoksydantnoi systemy u ditei riznoho viku [State of lipid peroxidation and antioxidant system in children of all ages]. Perinatologiya i pediatriya - Perinatology and Pediatrics, 2, 101-105 [in Ukrainian].

9. Khudan-Tsilio, I.I., \& Korda, M.M. (2017). Strukturni zminy shkiry pry kontaktnomu nikelevomu dermatyti [Structural skin changes in contact nickel dermatitis]. Visnyk morfolohii - Bulletin of Morphology, 2, 23, 198-202 [in Ukrainian].

10. Kostner, L., Anzengruber, F., Guillod, C., Recher, M., Schmid-Grendelmeier, P., \& Navarini, A.A. (2017). Allergic contact dermatitis. Immunology and Allergy Clinics, 37 (1), 141-152.

11. Beeckman, D., Campbell, J., Chimentro, D., Chimentao, D., Coyer, F., Domansky, R., ..., \& Wang, L. (2015). Incontinence associated dermatitis: moving prevention forward. Proceedings of the Global IAD Expert Panel. Wounds International.

12. Ji, H., \& Li, X.K. (2016). Oxidative stress in atopic dermatitis. Oxidative Medicine and Cellular Longevity.

13. Fried, R. (1975). Enzymatic and nonenzymatic assay of superoxide ifilli. Biochemie, 57 (5), 657-660.

14. Holmes, R., \& Masters, C. J. (1970). Masters with epigenetic interconversions of the multiple forms of mouse liver catalase. FEBS Lett, 11 (1), 45-48.

15. Kubesy, A.A., Salem, N.Y., \& Jaheen, A.H. (2017). Altered blood oxidative stress biomarkers in association with canine pyoderma and allergic contact dermatitis. Comparative Clinical Pathology, 26 (3), 643-646.

16. Lim, H.W., Collins, S.A., Jr Resneck, J.S., Bolognia, J.L., Hodge, J.A., Rohrer, T.A., \& Moyano, J.V. (2017). The burden of skin disease in the United States. Journal of the American Academy of Dermatology, 76, 958-972. 


\title{
Львовский медицинский институт
}

ОМ. М. Регеда-Фурдичко

\begin{abstract}
РЕЗЮМЕ. Цель работы - изучить состояние прооксидантной и антиоксидантной систем в коже морских свинок в разные периоды формирования экспериментального контактного дерматита.

Материал и методы. Исследования проводили на морских свинках, поделенных на пять груп: I группа - контрольная, II - 4-е сутки эксперимента, III - 8-е сутки развития контактного дерматита, IV - 10-е сутки и V-18-е сутки модельного процесса. Ранний период включал группу животных на 4-е и 8-е сутки эксперимента. Поздний - морские свинки на 10-е и 18-е сутки контактного дерматита. Экспериментальная модель контактного дерматита воспроизводилась методом В. А. Волкова (2010). Состояние свободнорадикального окисления липидов в коже определяли по содержанию диеновых коньюгатов методом В. Г. Гаврилова, М. И. Мышкорудной (1989), и малонового диальдегида методом Е. Н. Коробейникова (1989). Степень активности антиоксидантной защиты оценивали по содержанию ферментов супероксиддисмутазы методом R. Fried (1975), каталазы - методом B. Holmes, C. Masters (1970), глутатионредуктазы методом В. М. Моина (1986) и глутатионпероксидазы методом О. Г. Архиповой (1988).

Результаты. В работе установлен постепенный рост продуктов свободнорадикального окисления - диеновых конъюгатов и малонового диальдегида - на всех этапах формирования экспериментального контактного дерматита. Установлено первоначальное повышение активности супероксиддисмутазы, каталазы, глутатионредуктазы и глутатионпероксидазы в коже на 4-е сутки, с последующим снижением этих ферментов с 8-х суток эксперимента, что свидетельствовало о нарушении равновесия между прооксидантной и антиоксидантной системами, особенно на 10-е и 18-е сутки исследования, что усиливает воспалительный процесс в коже, а также запускает каскад других механизмов повреждения.
\end{abstract}

КЛючЕВЫЕ СЛОВА: контактный дерматит; малоновый диальдегид; диеновые коньюгаты; супероксиддисмутаза; каталаза; глутатионпероксидаза; глутатионредуктаза.

\section{THE ROLE OF LIPID PEROXIDATION AND ANTIOXIDANT PROTECTION IN SKIN IN THE DYNAMICS OF DEVELOPMENT OF EXPERIMENTAL CONTACT DERMATITIS}

\section{Lviv Medical Institute}

@M. M. Regeda-Furdychko

The aim of the work - to study the conditions of prooxidant and antioxidant system in the skin of guinea pigs in different periods of contact dermatitis formation.

Material and Methods. Researches were conducted on guinea pigs, divided into five groups: I - control, II - 4th day of expirement, III - 8th day of contact dermatitis development, IV - 10th day and V - 18th day of model process. Early period included groups of animals on the 4 th and 8th days of experiment. The late one - guinea pigs on the 10 th and 18 th days of contact dermatitis. Experimental contact dermatitis was simulated by method of Volkova V. A. (2010). Condition of free radical lipid oxidization in the skin was determined on maintenance content of malonic dialdehyde by method of Korobeynykov E. H. (1989) and diene conjugates by method of Havrylov V. H., Myshkorudna M. I. (1989). The degree of activity of antioxidant defence was estimated on maintenance enzymes - superoxidedismutase by R. Fried method (1975), catalase by B. Holmes, C. Masters method (1970), Arkhipova O. G. glutationperoxidase method (1988) and glutationreductase by V. M. Moina method (1986).

Results and Discussion. Gradual increasing of lipid peroxydations products - malonic dialdehyde, diene conjugate had been determined on the 4th , 8th , 10th and 18th days of experimental contact dermatitis development in this research. Primary increasing of the indices of superoxidedismutase, glutationreductase, glutationperoxidase and catalase had been investigated in the skin on the 4th day with the following decreasing of these enzymes from the 8th day of experiment. It testified about imbalance in antioxidant and prooxydant systems, especially on the 10 th and 18 th days of the study, which exacerbates the inflammatory process in the skin and also triggers a cascade of other mechanisms of damage.

KEY WORDS: contact dermatitis; malonic dialdehyde; diene conjugate; superoxidedismutase; catalase; glutationperoxidase; glutationreductase. 